\title{
Dendrochronological reconstruction of fire history in coniferous forests in the Monarch Butterfly Biosphere Reserve, Mexico
}

\author{
Jesús E. Sáenz-Ceja ${ }^{1,2}$ and Diego R. Pérez-Salicrup ${ }^{2^{*}}$ (D)
}

\begin{abstract}
Background: Some have proposed that fire return intervals lengthen with elevation in montane tropical coniferous forests, such as those found in central Mexico. This would generate patterns of synchronous tree establishment in higher elevation forests dominated by Abies sp. Mill., and patterns of continuous tree establishment in lower elevation forests dominated by Pinus sp. L. However, it is common to find codominant stands of both genera at intermediate elevations. The Monarch Butterfly Biosphere Reserve (MBBR) is located in this region, and is covered by Abies religiosa (Kunth) Schltdl. \& Cham-dominant forest, A. religiosa-Pinus pseudostrobus Lindley-codominant forest, and P. pseudostrobus-dominant forest. Despite the ecological importance of the MBBR's coniferous forests, little is known about their fire return intervals, including their relationship with climate, and their effects on tree establishment patterns according to the elevational range proposed above. In this study, using dendrochronological techniques, we reconstructed the historical fire return intervals for each forest type, evaluated their relationship with droughts and with the El Niño Southern Oscillation (ENSO), and assessed the effect of fire return intervals on tree establishment patterns. A total of 110 cross-sections were obtained, from 23 sites across the MBBR.

Results: The fire chronology covered the period between 1925 and 2015. Fire return intervals averaged two years in stands dominated by A. religiosa, by P. pseudostrobus, and codominated by both species, regardless of elevation. No fire-free periods were detected, even after the establishment of the reserve in 2000. Fire frequency was not associated with periods of drought and ENSO. There was no relationship between fire return intervals and patterns of tree establishment, which was continuous in all three forest types.

Conclusions: Our results suggest that coniferous forests of the MBBR have historically experienced frequent fires that are unrelated to climate and tree establishment. This may be evidence that natural fire regimes in these coniferous forests have been drastically altered by human activities. Although these frequent low-severity fires could adversely affect tree regeneration, and eventually decrease the integrity of the overwintering habitat of the Monarch Butterfly, the continuous tree regeneration observed suggests that these effects have not yet taken place.
\end{abstract}

Keywords: fire regime, montane tropical coniferous forest, tree establishment

\footnotetext{
* Correspondence: diego@cieco.unam.mx

${ }^{2}$ Instituto de Investigaciones en Ecosistemas y Sustentabilidad, Universidad

Nacional Autónoma de México, 8701 Antigua Carretera a Pátzcuaro,

Exhacienda de San José de la Huerta, Morelia, Michoacán 58190, México

Full list of author information is available at the end of the article
} 


\section{Resumen}

Antecedentes: Se ha propuesto que los intervalos de retorno de incendios se prolongan con la elevación de los bosques de coníferas tropicales de montaña, como los que se encuentran en el centro de México. Esto generaría patrones de establecimiento sincrónico de árboles en bosques de mayor elevación dominados por Abies sp. Mill., y patrones de establecimiento continuo de árboles en bosques ubicados a alturas menores dominados por Pinus sp. L. Sin embargo, es común encontrar rodales co-dominantes de ambos géneros en elevaciones intermedias. La Reserva de la Biosfera Mariposa Monarca (RBMM) está ubicada en esta región y está cubierta por bosques dominados por Abies religiosa (Kunth) Schltdl. \& Cham, co-dominados por A. religiosa y Pinus pseudostrobus Lindley, y bosques dominados por $P$. pseudostrobus. A pesar de la importancia ecológica de los bosques de coníferas de RBMN, se sabe poco acerca de sus intervalos de retorno de incendios, incluida su relación con el clima y sus efectos en los patrones de establecimiento de árboles de acuerdo con el rango de elevación propuesto anteriormente. En este estudio, reconstruimos los intervalos históricos de retorno de fuego para cada tipo de bosque utilizando técnicas dendrocronológicas, evaluamos su relación con las sequías y con el Niño-Oscilación del Sur (ENOS), y evaluamos el efecto de los intervalos de retorno de fuego en los patrones de establecimiento de árboles. Se obtuvieron un total de 110 secciones transversales, de 23 sitios en toda la RBMM.

Resultados: La cronología de incendios abarcó el período comprendido entre 1925 y 2015. Los intervalos de retorno del fuego promediaron dos años en rodales dominados por A. religiosa, por P. pseudostrobus y codominados por ambas especies, independientemente de la elevación. No se detectaron períodos libres de incendios, incluso después del establecimiento de la Reserva en 2000. La frecuencia de los incendios no se asoció con los períodos de sequía y ENOS. No hubo una relación entre los intervalos de retorno del fuego y los patrones de establecimiento de árboles, que fue continuo en los tres tipos de bosques.

Conclusiones: Nuestros resultados sugieren que los bosques de coníferas de RBMM han experimentado históricamente incendios frecuentes que no se asocian con el clima y el establecimiento de árboles. Esto puede ser una evidencia de que los regímenes de incendios naturales en estos bosques de coníferas han sido alterados drásticamente por las actividades humanas. Si bien estos incendios frecuentes y de baja severidad podrían afectar negativamente a la regeneración de árboles y, eventualmente, disminuir la integridad del hábitat de hibernación de la mariposa monarca, la continua regeneración de árboles observada sugiere que estos efectos aún no han tenido lugar.

\section{Abbreviations}

D: Dormant

EE: $\quad$ Early earlywood

ENSO: El Niño Southern Oscillation

L: $\quad$ Latewood

LE: Late earlywood

masl: Meters above sea level

MAX: Maximum fire interval

MBBR: Monarch Butterfly Biosphere Reserve

ME: $\quad$ Middle earlywood

MFI: Mean fire interval

MIN: Minimum fire interval

WMPI: Weibull mean probability interval

\section{Background}

Fire is a disturbance agent that influences forest regeneration in the sub-humid temperate zone (sensu Holdrige 1947), particularly in coniferous forests (Frelich 2002). To maintain the integrity of these forest ecosystems, management must take into account their natural disturbance regimes, under the premise that species have evolved under a historical disturbance regime (Franklin et al. 1997; Pérez-Salicrup et al. 2016). The fire regime of a given ecosystem can be characterized as the temporal distribution (duration, frequency, return interval, and seasonality), the spatial distribution (extent, shape, and ignition points), and the characteristics (vegetation type affected, behavior, severity, and intensity) of fires (Agee 1993; Krebs et al. 2010). Because the species present in coniferous forests have evolved in response to fire regimes, and not to individual fires, it is essential to understand what the current fire regime is, and to evaluate how far departed it may be from the historic regime (Fulé et al. 2009).

The fire return interval has been one of the most relevant and studied properties of fire regimes and is defined as the historical temporal pattern of fire occurrence in a given location (Heyerdahl et al. 2011). The reconstruction of fire return intervals can help identify the relationship between fire occurrences with regional climatic patterns, such as periods of drought (Fulé et al. 2005; Gill and Taylor 2009), or with global circulation phenomena, such as El Niño Southern Oscillation (ENSO; Heyerdahl and Alvarado 2003; Yocom et al. 2010). It can also be used to evaluate whether fire frequency is associated with forest structure at a local scale (Brown 2006), 
or whether there is a relationship between fire return intervals and insect outbreaks (Kulakowski and Jarvis 2011). A reconstruction of historical fire return intervals may allow us to evaluate whether current fire frequency falls within the historical range of variation.

This reconstruction is possible through the dating of fire scars in the trunks of trees (Agee 1993). Fire scars are formed when there is sufficient duff and litter fuels at the tree base, facilitating a fire that is intense enough to penetrate the bark and damage the cambium, leading to an identifiable scar forming in the tree ring, corresponding to the fire year. In some species of conifers, it is possible to know precisely the year and season in which the fire occurred and, as trees continue to grow, the fire scars are surrounded by wound wood (Gutsell and Johnson 1996). This process can be repeated, so a given tree can register several fire events (Baker and Dugan 2013). Contiguous trees are likely to record the same years of fire, which allows for the reconstruction of the history of fires for a stand or a complete region.

During the last 40 years, the interest in reconstructing the history of fires has grown in different regions (Agee 1993; Fulé et al. 2005; Poulos et al. 2013). During most of the twentieth century, a fire suppression policy was developed in the United States of America and in other parts of the world, which considerably increased fire return intervals and led to a high accumulation of fuels. This modification of fire regimes contributed to increases in uncharacteristically intense and severe fires and the loss of species in places where frequent low-severity surface fires historically predominated (Pyne 1996). Consequently, interest increased in understanding the role of climatic and human factors on the occurrence of fires (Lethonen et al. 1996), as both can modify forest structure and generate synergies of forest fires with other disturbances (Abrams and Orwig 1996; Bergeron 1998). Fire return intervals determine the length of periods of fuel accumulation, plant growth, and recolonization and regeneration of plant populations (Davies 2013). Understanding temporal fire dynamics and its role in the regeneration of coniferous species has been used for planning of prescribed burning, timber harvesting, and design of restoration strategies based on the re-establishment of fire return intervals in sites that have experienced fire suppression (Mast et al. 1999).

Fire regimes are not homogeneous across all coniferous forests (Agee 1993). For example, in some pine-dominated forests, such as those dominated by Pinus ponderosa Douglas ex Lawson, frequent and low-moderate severity fires are often experienced, which usually result in the continuous establishment of new individuals through time (Brown and Cook 2006). In contrast, forests dominated by genera such as Abies Mill. and Picea A. Dietr. experience infrequent crown fires, with mixed or high severity, which generally initiate stand replacement, which in turn results in synchronous or pulsed establishment patterns in tree populations (Shawn et al. 2008). This fire regime pattern may be found along an elevational gradient in which frequent and low-severity fires are experienced in forests located at low elevations (e.g., P. ponderosa forests), and infrequent and mixed- or high-severity fires at high elevations (e.g., Abies concolor [Gordon \& Glenndinig] Hoopes stands) (Fulé and Laughlin 2007).

In Mexico, coniferous forests are distributed in mountainous areas and show high genetic and species diversity (Gugger et al. 2013). It has even been proposed that, in montane tropical regions in Mexico such as the TransMexican Volcanic System (TVS) and Sierra Madre del Sur, fire return intervals are shorter compared with their boreal or austral counterparts (Yocom and Fulé 2012). Furthermore, fire regimes may vary according an elevational gradient, due to the large elevational variation of the mountainous massifs in this tropical region. On the highest peaks of the TVS, above $3400 \mathrm{~m}$, forests are dominated by Pinus hartwegii Lindley. Below this elevation, forests are dominated by fir species, such as Abies religiosa (Kunth) Schltdl. \& Cham or Abies hickelii Flous \& Gaussen, and then by several pine species, such as Pinus pseudostrobus Lindley or Pinus montezumae Lamb. at the lowest elevations (Sáenz-Ceja and Pérez-Salicrup 2019). In addition, in these montane forests, it is common to find a mid-elevation zone with codominance of both genera (Sáenz-Ceja 2015). It has been proposed that fire regimes could vary between fir forests, with infrequent fires of mixed severity and intensity, and pine forests, with frequent fires of low severity and intensity (Rodríguez-Trejo and Fulé 2003). However, this fire regime pattern has not been assessed in forest dominated and codominated by both genera.

The scarcity of studies documenting fire return intervals or any of the other attributes associated with current fires regimes in montane tropical coniferous forests contrasts with a greater number of fire chronologies developed in northern Mexico, where coniferous forests, in general terms, experience frequent surface low-severity fires (Fulé et al. 2012). Most of these forests have synchronous fire return intervals that are strongly associated with ENSO oscillations, and, in some places, fire regimes have changed by local processes such as forest management and fire suppression (Yocom et al. 2017). Most sites in northern Mexico, however, did not experience fire suppression or reduction of fire return intervals until the second half of the twentieth century, when logging became an important activity after the formation of the ejidos in 1936 (Heyerdahl and Alvarado 2003). The ejido is a social land tenure created after the Mexican Revolution in which groups of peasants received extensive pieces of land. Almost 63 
million hectares of Mexican forests belong to ejidos and indigenous communities (Morett-Sánchez and Cosío-Ruiz 2017). In the few studies in montane tropical coniferous forest ecosystems of central Mexico, the forests have been documented to experience frequent and low-severity fires in sites dominated by Pinus douglasiana Martínez (Cerano-Paredes et al. 2015) and P. hartwegii (CeranoParedes et al. 2016). It has been suggested that ENSO does not modulate fire frequency with the same force in these central Mexican forests as it does in the northern Mexican forests (Yocom and Fulé 2012), and that the effect of human activities could have strongly modified natural fire regimes (Pompa-García et al. 2017).

The Monarch Butterfly Biosphere Reserve (MBBR), located in the Trans-Mexican Volcanic System, is mainly covered by coniferous forests dominated by fir (A. religiosa) at elevations higher than 3150 meters above sea level (masl), codominated by pine-fir ( $P$. pseudostrobusA. religiosa) stands between 2800 to 3150 masl, and dominated by pine ( $P$. pseudostrobus) at elevations lower than 2800 masl (Sáenz-Ceja 2015; Cornejo-Tenorio and Ibarra-Manríquez 2017). This reserve is the place where millions of monarch butterflies overwinter each year, from November to March, particularly in A. religiosa stands (Brower et al. 2016). A recent study suggested that human disturbances have reduced the fir forest surface; that is, the habitat of monarch butterflies (Vidal et al. 2014). Climate change could also reduce the extent of $A$. religiosa stands, due to higher aridity conditions affecting fir tree phenology (Sáenz-Romero et al. 2012). In addition, there is evidence of the modification of fire regimes, indicated by the age structure of dominant and codominant stands (Pérez-Salicrup et al. 2016). Changes in natural fire regimes, particularly in fir forests, could put at risk the migratory phenomenon of monarch butterflies, as fire suppression or increased fire frequency could alter tree population structure and tree establishment patterns, and negatively affect the sanctuaries where the butterflies hibernate. Hence, the development of a fire chronology in the MBBR is essential to document the historical fire return intervals as well as their relationship with climatic and tree regeneration patterns.

The objectives of this study were: 1 ) to reconstruct the history of fires in forests dominated and codominated by P. pseudostrobus and A. religiosa, 2) to evaluate whether the fire return intervals differ between the forests dominated and codominated by both species, 3) to evaluate whether climate is related to fire frequency in this region, and 4) to evaluate whether tree regeneration in the three forest types responds to fire frequency. This will provide important information toward understanding the influence of fire on the structure of montane tropical coniferous forests. In addition, it will be useful to design forest management strategies that could provide long-term preservation of monarch butterfly habitat. We expected to find the following: (1) that fire return intervals varied among fir, mixed pine fir, and pine forests; (2) that drought periods and ENSO oscillations strongly influenced fire frequency; and (3) that tree establishment in fir stands following fires was synchronic, whereas it was continuous in pine stands.

\section{Methods \\ Study site}

The MBBR is located between the states of Mexico and Michoacán, in central Mexico, with an extent of 56256 hectares (Fig. 1) and coordinates between $19.7408 \mathrm{~N}$, $-100.3738 \mathrm{~W}$, and $19.3089 \mathrm{~N},-100.1519 \mathrm{~W}$ (CONANP 2001). The area is dominated by volcanic soils and a rugged topography, with elevations ranging from 2220 to 3640 masl (Ramírez-Ramírez 2001). Physiographically, it is part of the Trans-Mexican Volcanic System (SánchezGonzález et al. 2005). Climate is sub-humid temperate and sub-humid semi-cold, with rainy season from July to October, mean annual temperatures ranging from $8^{\circ} \mathrm{C}$ to $22{ }^{\circ} \mathrm{C}$, and mean annual precipitation between 700 and $1250 \mathrm{~mm}$ (García 1997). There are four major vegetation types: coniferous forest, oak forest, mesophilic mountain forest, and montane grasslands (CornejoTenorio and Ibarra-Manríquez 2017). Coniferous forests are the most extensive vegetation type, with $12 \%$ of the MBBR area dominated by A. religiosa, $33 \%$ dominated by $P$. pseudostrobus, and $27 \%$ codominated by both species (Sáenz-Ceja 2015; Fig. 2).

Initially, the area of the MBBR mainly covered the fir stands surrounding the overwintering colonies of monarch butterflies. In 2000, the reserve acquired its current configuration, including mixed pine-fir and pine stands at lower elevations (Vidal et al. 2014). Most of the MBBR area is property of rural communities; specifically, of 59 ejidos and 13 indigenous communities. Only a small area belongs to the state and federal governments (Martínez-Torres et al. 2016). Historically, the forests of the MBBR have been managed. In the buffer zone, particularly in mixed pine-fir and pine stands, commercial logging is allowed under certain restrictions, following a selective logging method (Navarrete et al. 2011), while salvage logging in the core zone is allowed only after severe blizzards and bark beetle detections (Brower et al. 2017). No large insect outbreaks had been documented in the MBRR in the last 15 years (Camarillo-Luna 2018). The MBBR is inhabited by more than 27000 people (INEGI 2010). Firewood harvesting and livestock grazing are two important human activities inside the forests (Honey-Róses 2009), while some stands have been affected by illegal logging, particularly in fir and mixed pine-fir forests in the core zone (Brower et al. 2016). 


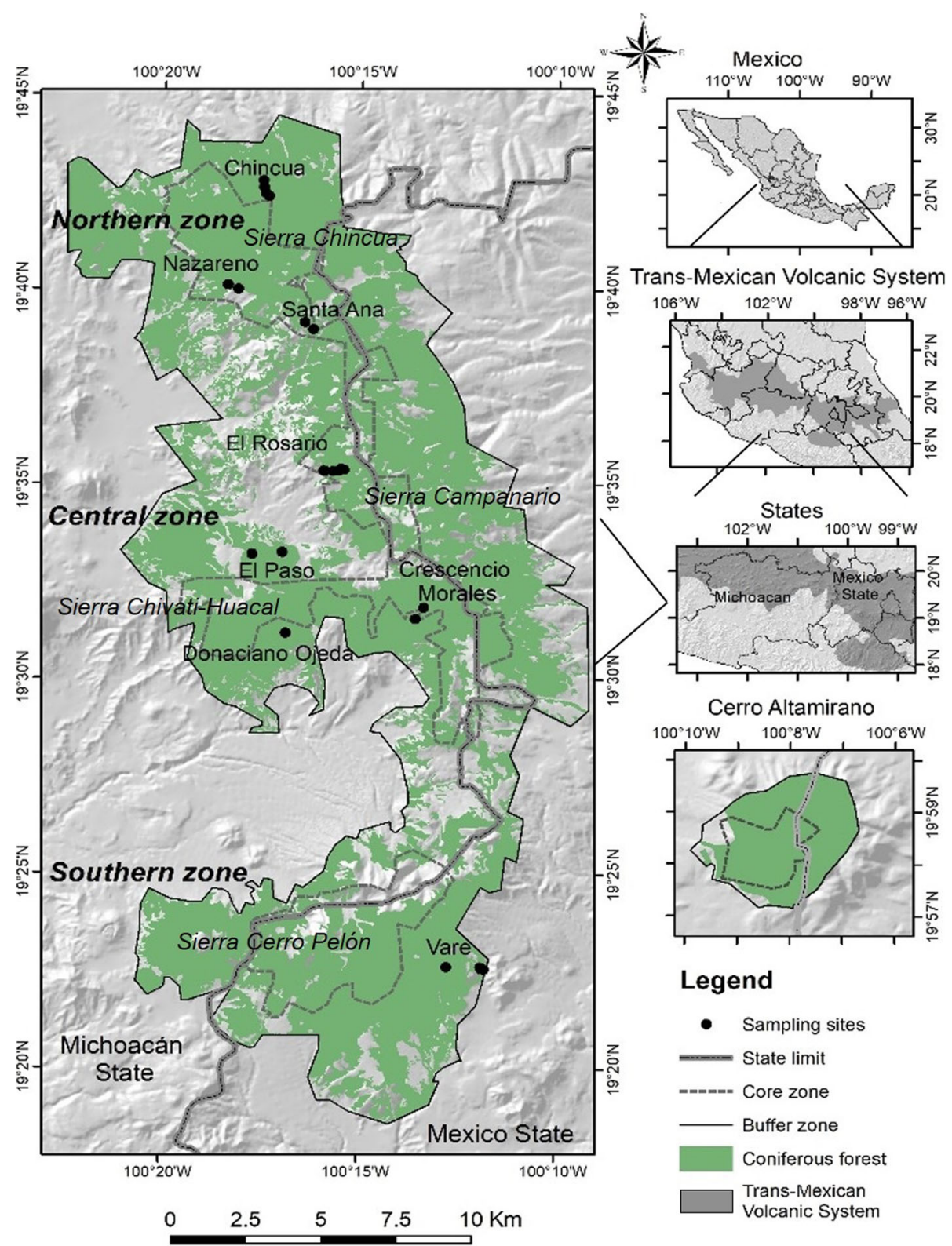

Fig. 1 Location of the Monarch Butterfly Biosphere Reserve, Mexico, and fire-scar sampling sites in 2016

Fire is a historical disturbance in the forests of the MBBR. Some rural inhabitants of the MBBR have even developed a traditional fire management knowledge system, particularly to eliminate agricultural residues, to promote grassland for animal husbandry, for the extraction of non-timber products, and for cleaning roads (Martínez-Torres et al. 2016). Fires occur mainly during the dry season (from March to June). The main sources of ignition reported are agricultural activities, forestry, and campfires. No lightning fires have been reported (Pérez-Salicrup et al. 2016). Most of fires reported since the year 2012 had a mean extent of 2 ha, and were surface, low-severity, and low-intensity fires, in pine, mixed pine-fir, and fir stands (Cantú-Fernández 2013). There is an official policy of fire fighting, carried out by rural communities, and state and federal brigades (MartínezTorres et al. 2015).

\section{Dendrochronological sampling}

We established 23 sampling sites following an elevational gradient between 2700 and 3200 masl that included the distribution elevation of pine forests dominated by $P$. pseudostrobus (2700 to 2850 masl); mixed pine-fir forests, codominated by $P$. pseudostrobus and A. religiosa (2850 to 3150 masl); and fir forests, dominated by $A$. religiosa (3150 to 3300 masl). The sampling sites were located 


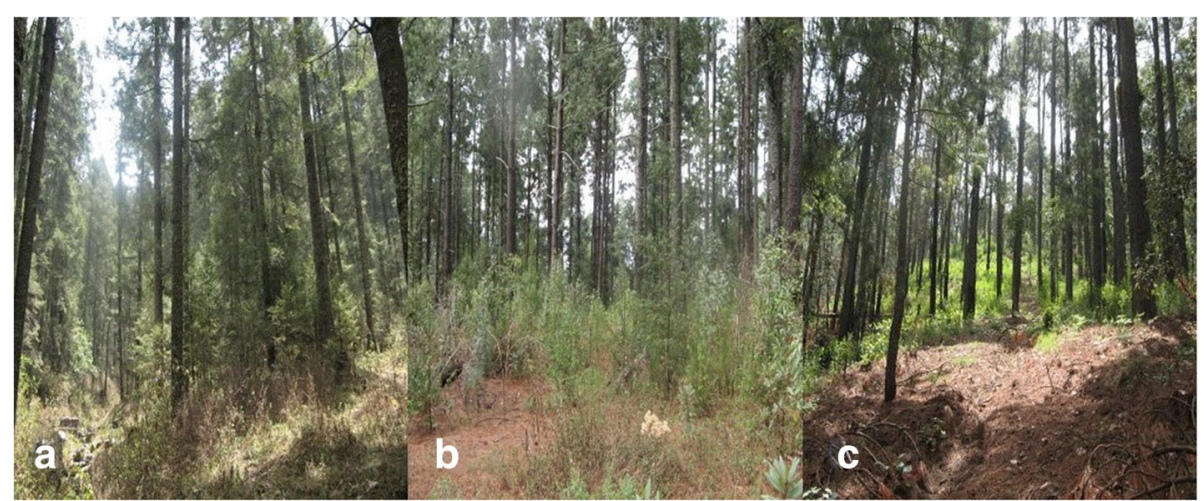

Fig. 2 Fir forest (a), mixed pine-fir forest (b), and pine forest (c) in the Monarch Butterfly Biosphere Reserve, Mexico, in 2016. Photo credit: J.E. Sáenz-Ceja

within the contiguous MBBR, along the ChincuaCampanario. Cerro Pelon corridor, and associated with the three main massifs of the area: Sierra de Chincua in the northern zone (ejidos Chincua, Jesús Nazareno, and Santa Ana); Sierra Campanario-Chivati-Huacal in the central zone (ejidos El Paso, El Rosario, Donaciano Ojeda, and Crescencio Morales), and Sierra Cerro Pelón in the southern zone (ejido Vare). The detached portion of the MBBR, called Cerro Altamirano, $30 \mathrm{~km}$ north of the main portion, was not considered in this study (Fig. 1). The sites were selected in stands that experienced past fires, with regard to testimony of forest owners as well as to the presence of fire-scars in living trees, stumps, and fallen trees (Fig. 3a). Because the decaying of fallen trees and stumps is relatively fast, we focused our sampling in sites that had recently experienced salvage logging (in response to a blizzard in 2016) or commercial logging. The characteristics of the sampling sites and the number of samples are showed in Table 1. No living trees were sampled, due to restrictions of forest owners. Stumps and felled firescarred trees were selected in each site, from which cross-sections were extracted with a chainsaw (Fig. 3b).
We measured the diameter $(\mathrm{cm})$ at the base of each stump or tree, and recorded the species.

\section{Fire scar dating}

The cross-sections were dried, sanded, and polished using standard dendrochronological techniques (Speer 2010). Age was first estimated by counting the radial growth rings, and skeleton plots were generated to cross-date all samples, which were compared with a master chronology of $A$. religiosa and $P$. pseudostrobus developed for the MBBR (Carlón-Allende et al. 2016). This allowed us to identify missing rings, micro rings, and false rings, and to date samples for which the cut year was unknown. Once samples were dated, years with fire scars were identified by the interruption of growth rings and the presence of charcoal, followed by deformation and generation of wound wood (Gutsell and Johnson 1996). According to the clarity of the scar, the annual season of each fire was recorded as early earlywood (EE), middle earlywood (ME), late earlywood (LE) (Grissino-Mayer 2001). No latewood (L) or dormant (D) scars were found. The categories were grouped into two periods: dry season $(\mathrm{EE}+\mathrm{ME})$ and wet

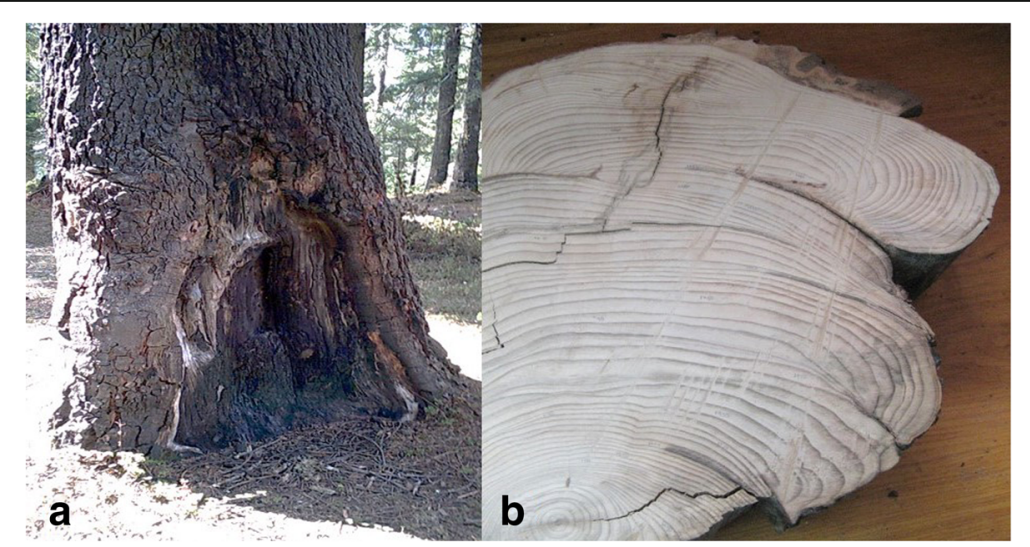

Fig. 3 Monarch Butterfly Biosphere Reserve, Mexico, fire-scarred tree (a), and a cross-section (b), in 2016. Photo credit: J.E. Sáenz-Ceja 
Table 1 Sampling site characteristics in the Monarch Butterfly Biosphere Reserve, Mexico, listed from northern to southern zones

\begin{tabular}{|c|c|c|c|c|c|c|c|}
\hline Zone & Ejido & Site & Elevation (masl) & Latitude & Longitude & Forest dominance & Samples $(n)$ \\
\hline \multirow[t]{8}{*}{ North } & \multirow[t]{2}{*}{ Santa Ana } & Llano1 & 3177 & 19.6526 & -100.2739 & Fir & 4 \\
\hline & & Llano2 & 3049 & 19.6497 & -100.2702 & Fir & 6 \\
\hline & \multirow[t]{2}{*}{ Nazareno } & La Cueva1 & 3049 & 19.6668 & -100.3021 & Fir & 4 \\
\hline & & La Cueva2 & 2877 & 19.6687 & -100.3063 & Fir & 3 \\
\hline & \multirow[t]{4}{*}{ Chincua } & Remplaces & 3104 & 19.7067 & -100.2893 & Pine-fir & 6 \\
\hline & & Remplaces2 & 3063 & 19.7080 & -100.2908 & Pine-fir & 6 \\
\hline & & Mojonera & 3019 & 19.7104 & -100.2914 & Pine-fir & 5 \\
\hline & & Loma En Medio & 3009 & 19.7132 & -100.2916 & Pine & 3 \\
\hline \multirow[t]{11}{*}{ Central } & \multirow[t]{6}{*}{ El Rosario } & El Deslave & 3227 & 19.5901 & -100.2580 & Fir & 3 \\
\hline & & La Peñita & 3251 & 19.5896 & -100.2568 & Fir & 2 \\
\hline & & Las Palmas & 3200 & 19.5892 & -100.2591 & Fir & 7 \\
\hline & & Santuario3 & 3149 & 19.5889 & -100.2614 & Fir & 3 \\
\hline & & Santuario2 & 3120 & 19.5891 & -100.2649 & Pine-fir & 3 \\
\hline & & Santuario1 & 3109 & 19.5893 & -100.2653 & Pine-fir & 3 \\
\hline & \multirow[t]{2}{*}{ El Paso } & La Mesa & 2935 & 19.5542 & -100.2828 & Pine-fir & 10 \\
\hline & & Cruz Chiquita & 2896 & 19.5534 & -100.2955 & Pine-fir & 6 \\
\hline & \multirow[t]{2}{*}{ Crescencio } & Choreje Grande & 3115 & 19.5308 & -100.2228 & Pine-fir & 3 \\
\hline & & Choreje Chico & 2850 & 19.5259 & -100.2263 & Pine-fir & 3 \\
\hline & Donaciano & Ojo de Agua & 2851 & 19.5196 & -100.2812 & Pine & 3 \\
\hline \multirow[t]{4}{*}{ South } & \multirow[t]{4}{*}{ Vare } & Antenas & 3273 & 19.3768 & -100.2124 & Fir & 2 \\
\hline & & Vare2 & 2850 & 19.3768 & -100.1980 & Pine & 8 \\
\hline & & Vare1 & 2780 & 19.3761 & -100.1975 & Pine & 9 \\
\hline & & Vare3 & 2732 & 19.3758 & -100.1965 & Pine & 7 \\
\hline
\end{tabular}

season (LE). The earlywood in both species is formed from May to September (end of dry season and beginning of wet season), and latewood from October to December (end of wet season) (Carlón-Allende et al. 2018).

\section{Fire return interval estimation}

The fire return interval for each site was estimated using the Weibull median probability interval (WMPI), the maximum interval (MAX), and the minimum interval (MIN) (Grissino-Mayer 2001). We preferred the WMPI because fire return intervals are seldom normally distributed and WMPI resists large fire interval values (Grissino-Mayer 1999). These data were analyzed using three filters: (1) considering $100 \%$ of the scars, (2) considering only the scars present in $\geq 10 \%$ of samples, and (3) considering scars present in $\geq 25 \%$ of samples. Since we followed an elevational gradient to select the sampling sites, the spatial scale considered for computing these values was the extent of the three forest types in the MBBR, which was 7153 ha for fir forest, 15078 ha for mixed pine-fir forest, and 18462 ha for pine forest, estimated in a preliminary study (Sáenz-Ceja 2015). Within zones, we assumed that, in years with a low percentage of scars, small fires occurred, while years with a high percentage of scars represented fires of greater extent (Fulé et al. 2003). However, fires that registered in the same year were not assumed to represent the same fire when the distance between samples was large (i.e., across the northern, central, and southern regions of our study area), because of the broken topography of the terrain. Data were analyzed with the FHAES program v. 2.0.2 (Brewer et al. 2016). In addition, we documented the total number of scars, the number of years with records of fires, and the time lapse from the first to the last year of recorded fire, and we analyzed the sample size needed to determine the threshold beyond which the number of samples was representative for the chronologies of each forest type. Trees with scars in the same site and for the same year were composited.

\section{Fire and climate analysis}

We conducted a superposed epoch analysis (SEA) using FHAES 2.0.2 to evaluate the relationship between fire occurrence and climate conditions, such as precipitation 
and ENSO (Brewer et al. 2016). The tree-ring width index of a chronology developed for $A$. religiosa and $P$. pseudostrobus in the MBBR was used as a precipitation proxy, covering the period 1890 to 2012 (Carlón-Allende et al. 2016). Values for the winter-spring (December to April) period (1870 to 2015) of the ENSO index were used, with data for the period 1870 to 1950 obtained from Cook (2000), and for the period 1951 to 2015 from NOAA (2017). The tree-ring width and ENSO indexes were compared with the fire chronology of five years previous, during the year of fire, and two years later. The confidence intervals of the SEA analysis $(95 \%, 99 \%$, and $99.9 \%)$ were calculated using the bootstrapping with 10000 repetitions. Only years with scars present in $\geq 25 \%$ of samples were used for these analyses.

\section{Fire, climate, and tree establishment patterns}

The occurrence of fires was compared graphically with the tree-ring index (precipitation proxy) and the tree age structure to evaluate whether fires were associated with dry periods and the existence of pulses or continuous tree establishment. For the tree-ring width index, years with a mean value $<1$ were considered dry (Carlón-Allende et al. 2016). Tree establishment data of both conifer species were obtained from our 110 cross-sections and complemented with age structure data previously collected in the MBBR by Sáenz-Ceja (2015) and Carlón-Allende et al. (2016), in sites where our fire scar sampling was

Table 2 Forest type, number of trees cored, and names of collecting sites in this and two previous studies in the Monarch Butterfly Biosphere Reserve, Mexico

\begin{tabular}{|c|c|c|c|}
\hline Studies & Forest type & $\begin{array}{l}\text { Sampled } \\
\text { trees }(n)\end{array}$ & Sites \\
\hline \multirow[t]{3}{*}{ This study } & Fir forest & 34 & $\begin{array}{l}\text { Nazareno, Santa Ana, } \\
\text { El Rosario, Vare }\end{array}$ \\
\hline & $\begin{array}{l}\text { Mixed pine-fir } \\
\text { forest }\end{array}$ & 45 & $\begin{array}{l}\text { Chincua, El Paso, El } \\
\text { Rosario, Crescencio } \\
\text { Morales }\end{array}$ \\
\hline & Pine forest & 31 & $\begin{array}{l}\text { Chincua, Donaciano, } \\
\text { Vare }\end{array}$ \\
\hline \multirow[t]{3}{*}{ Sáenz-Ceja (2015) } & Fir forest & 150 & Vare \\
\hline & $\begin{array}{l}\text { Mixed pine-fir } \\
\text { forest }\end{array}$ & 275 & Nazareno, El Paso \\
\hline & Pine forest & 350 & Chincua, Vare \\
\hline \multirow[t]{3}{*}{$\begin{array}{l}\text { Carlón-Allende } \\
\text { et al. (2016) }\end{array}$} & Fir forest & 100 & $\begin{array}{l}\text { Santa Ana, Nazareno, } \\
\text { Vare }\end{array}$ \\
\hline & $\begin{array}{l}\text { Mixed pine-fir } \\
\text { forest }\end{array}$ & 63 & Crescencio Morales \\
\hline & Pine forest & 34 & Donaciano Ojeda \\
\hline
\end{tabular}

conducted (Table 2). Age structure data were classified according to the dominance of the stands (A. religiosa, $P$. pseudostrobus, or codominated). No establishment dates after 1991 are reported here because only trees with diameters $\geq 25 \mathrm{~cm}$ at $1.3 \mathrm{~m}$ in height were sampled. The youngest tree reported in these studies was established in 1991.

The sampled trees represented only a portion of the original trees established in the past, because some trees could have died (Johnson and Fryer 1989). Hence, we estimated the original number of trees established for each age using mortality rates reported for Pinus spp. (Gama-Orozco 2009) and Abies spp. (Ávila-Bello et al. 2015) populations of central Mexico. We used the following formula:

$$
N_{\mathrm{x}+1}=N_{\mathrm{x}} *\left(1-Q_{\mathrm{x}}\right),
$$

where $N_{\mathrm{x}+1}=$ population size at time $x+1, N_{\mathrm{x}}=$ population size of age $x$, and $Q_{\mathrm{x}}=$ mortality rate for age $x$.

\section{Results}

A total of 110 cross-sections were collected-50 of A. religiosa and 60 of $P$. pseudostrobus - 66 cross-sections came from stumps and 44 cross-sections from felled trees from a winter windthrow in 2016 (Table 1). In codominated sites, $56 \%$ of cross-sections were from A. religiosa, with the remainder from $P$. pseudostrobus. In mono-dominated sites, all samples came from the dominant species. All collected samples of both species were crossdated.

The diameter at the base of the stumps or felled trees in A. religiosa ranged from 20 to $105 \mathrm{~cm}$ and averaged $62 \mathrm{~cm}$. Age ranged between 24 and 166 years, with a mean of 82 years. For $P$. pseudostrobus, the diameter at the base ranged from 20 to $92 \mathrm{~cm}$, with a mean of $52 \mathrm{~cm}$. Age ranged between 32 and 132 years and averaged 75 years.

We crossdated a total of 326 fire scars and 239 fires. There were 67 years with recorded fires, which represented $38.7 \%$ of the years covered by the time series (137 years) from the first scar (1878) to the last scar (2015). Almost one third (32\%) of sampled trees had a single fire scar. As the number of scars per individual increased, the number of trees thus scarred decreased. The maximum number of scars for an individual of $A$. religiosa was 11 scars, while the maximum number of scars in P. pseudostrobus was 8 scars.

In sites dominated by $A$. religiosa, fires spanned 94 years (1921 to 2015); in codominated sites, fires spanned 137 years (1878 to 2015); and in stands dominated by $P$. pseudostrobus, fires spanned 109 years (1906 to 2015). For further analyses, we only considered fire data starting in 1925 because, before this date, only seven 
fire-scars were recorded and were not representative of the fire history during that period.

\section{Fire return intervals}

Fire return intervals were similar in the three coniferous forest of the MBBR. In A. religiosa-dominated sites, the WMPI was 2.2 years. When only fires recorded on $\geq 10 \%$ of samples ( $10 \%$ filter) were considered, the WMPI increased to 3.7 years; and when only fires recorded on $\geq 25 \%$ of samples ( $25 \%$ filter) were considered, this value increased to 14.6 years (Table 3). In the codominated sites, the WMPI was 2.2 years considering all scars, while for the $10 \%$ filter, the WMPI increased to 2.8 years. For the $25 \%$ filter, the WMPI was 7.5 years. In $P$. pseudostrobus sites, the WMPI was 3 years $(100 \%$ of samples) and 4.3 years ( $10 \%$ filter). For fires recorded on $\geq 25 \%$ of samples, the WMPI increased to 10.4 years. Grouping the sampled trees of the three coniferous forests, WMPI was 1.5 years. When applying the $10 \%$ and $25 \%$ filters, the WMPI increased to 3.7 and 9.8 years, respectively.

Minimum fire return intervals were similar across the three forest types, ranging between one and two years. Maximum fire return intervals varied according to the proportion of trees analyzed and forest type. In the $A$. religiosa-dominated sites, it was 6 years when considering all trees, 12 years for $\geq 10 \%$ of scarred trees, and 41 years for $\geq 25 \%$ of scarred trees. In codominated sites, the maximum fire return interval was 9 years for all scarred trees and for $\geq 10 \%$ of scarred trees, and

Table 3 Weibull median probability interval (WMPI) in years (yr \pm one standard error of the mean), minimum interval (MIN), and maximum interval (MAX), considering all fire scars sampled, only those present in $\geq 10 \%$ of scarred trees, and only those present in $\geq 25 \%$ of trees, in fir-, pine-fir-, and pine-dominated forests in the Monarch Butterfly Biosphere Reserve, Mexico

\begin{tabular}{llclc}
\hline Forest & Analysis category & WMPI (yr) & MIN (yr) & MAX (yr) \\
\hline Fir & All fire scars & $2.2 \pm 1.2$ & 1 & 6 \\
& $\geq 10 \%$ of scarred trees & $3.7 \pm 2.2$ & 1 & 12 \\
& $\geq 25 \%$ of scarred trees & $14.6 \pm 13.4$ & 2 & 41 \\
Pine-fir & All fire-scars & $2.2 \pm 1.3$ & 1 & 9 \\
& $\geq 10 \%$ of scarred trees & $2.8 \pm 1.5$ & 1 & 9 \\
& $\geq 25 \%$ of scarred trees & $7.5 \pm 4.6$ & 2 & 43 \\
Pine & All fire scars & $2.9 \pm 1.4$ & 1 & 7 \\
& $\geq 10 \%$ of scarred trees & $4.3 \pm 2.7$ & 2 & 15 \\
& $\geq 25 \%$ of scarred trees & $10.4 \pm 14.3$ & 2 & 50 \\
All & All fire scars & $1.5 \pm 0.7$ & 1 & 3 \\
& $\geq 10 \%$ of scarred trees & $3.7 \pm 2.3$ & 1 & 10 \\
& $\geq 25 \%$ of scarred trees & $9.3 \pm 13.6$ & 1 & 43 \\
\hline
\end{tabular}

increased to 43 years when considering $\geq 25 \%$ of scarred trees. In $P$. pseudostrobus-dominated sites, maximum fire return intervals were 7 years when considering the $100 \%$ of fire scars, 15 years when considering only $\geq 10 \%$ of scarred trees, and 50 years when considering $\geq 25 \%$ of scarred trees. Grouping the trees of the three coniferous forests, these values were 3 years for all trees, 10 years using the 10\% filter, and 43 years with the $25 \%$ filter.

During the analyzed period (1925 to 2015), sites dominated by $A$. religiosa experienced 41 years with fires when considering all trees, 24 years with fires affecting $\geq 10 \%$ of scarred trees, and only 6 years with fires affecting $\geq 25 \%$ of scarred trees. In codominated sites, 38 years were documented with fires when considering all trees with scars, 30 years with fires in $\geq 10 \%$ of trees, and 9 years with fires in $\geq 25 \%$ of scarred trees. In P. pseudostrobus sites, there were 31 years with fires when considering all trees with scars, 21 years with fires in $\geq 10 \%$ of scarred trees, and 5 fires in $\geq 25 \%$ of the samples.

There were 14 years in which all fire scars coincided in trees across the three different dominance types compared: 1936, 1947, 1957, 1969, 1974, 1979, 1986, 1991, 1994, 2001, 2004, 2006, 2013, and 2015. When only $\geq 10 \%$ of scarred trees were considered, there were six years with fires: 1936, 1969, 1979, 1991, 1994, and 2013. For the scars present in $\geq 25 \%$ of scarred trees, there was only one year with fires, 1936, but in 1938 and 1979, there were fires recorded in both $A$. religiosa and codominated sites.

Fires in the MBBR are frequent, since time return intervals are always $<15$ years when $\leq 25 \%$ of scarred trees are considered, and this estimate does not exceed five years when all trees in the sample are included. In addition, the fact that there were very few years in which scar years coincided suggests that small fires were the most common (Fig. 4).

\section{Seasonality}

The seasonality of fires was determined for all scars. No scars were recorded in the periods of dormancy (D) or latewood (L). In A. religiosa sites, $65.4 \%$ of sample scars were formed during ME; in codominated sites, $72.5 \%$; and in P. pseudostrobus sites, $88.1 \%$. In each forest type, most of the scars were observed during the dry season: $83.1 \%$ in fir forest, $84.6 \%$ in pine-fir forest, and $92.8 \%$ in pine forest. When grouping all the individuals, $72.4 \%$ of the scars occurred in the ME period, and $86.3 \%$ in the dry season (Table 4).

\section{Fires and climate}

In all three forest types, we did not find significant associations between climatic conditions and fire occurrence ( $P>0.05$ in all cases), even for the scars present in $\geq 25 \%$ of scarred trees (i.e., for the most extensive fires; Fig. 5). 


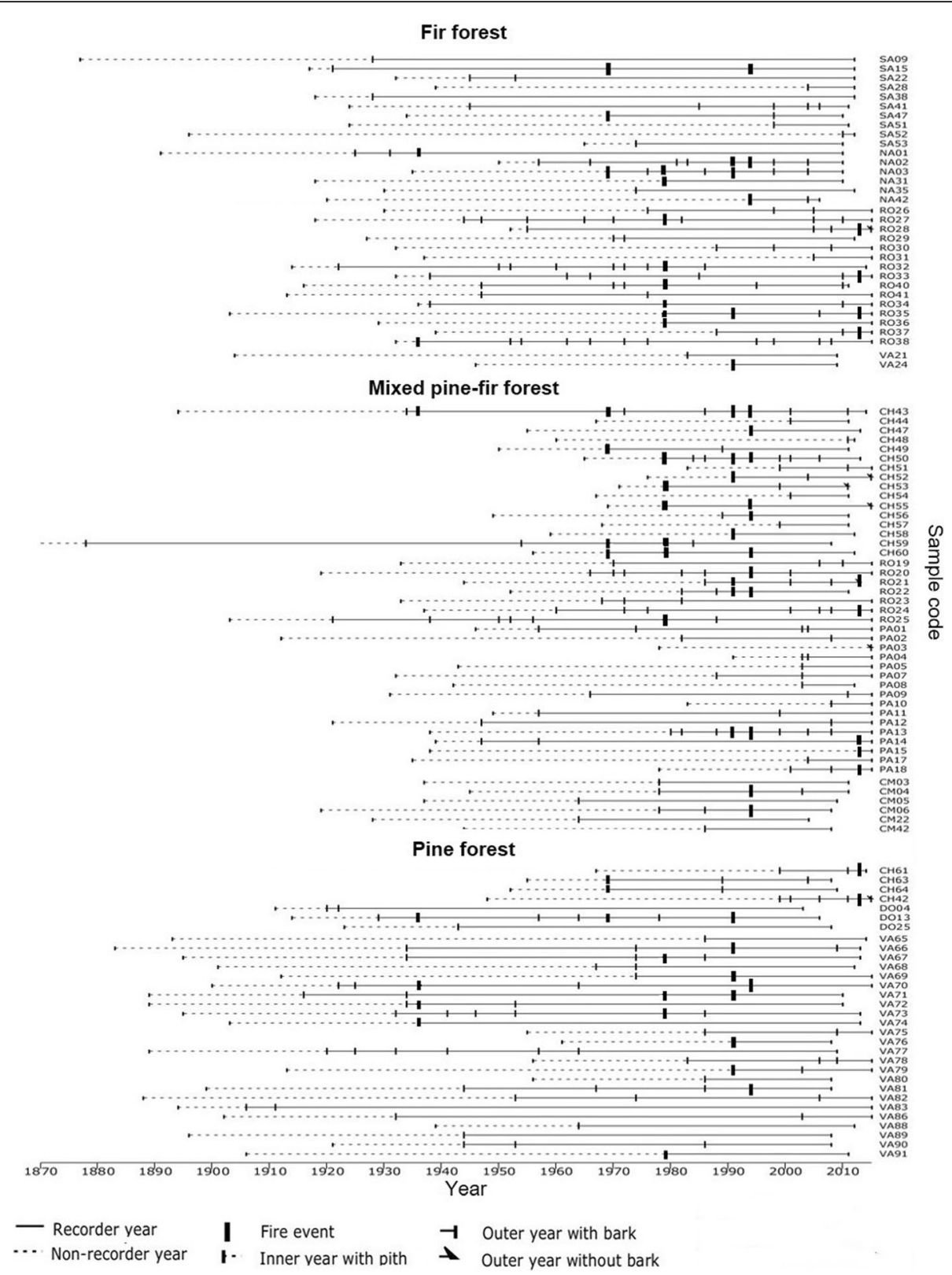

Fig. 4 Fire chronology in the Monarch Butterfly Biosphere Reserve, Mexico, in fir forest (sites dominated by A. religiosa), mixed pine-fir forest (sites codominated by both P. pseudostrobus and A. religiosa), and pine forest (sites dominated by P. pseudostrobus), for 100\% of the fire scars samples, spanning the years 1870 to 2015 . Years in which $\geq 10 \%$ of trees were fire scarred are highlighted with heavy black bars $(1936,1969,1979,1991,1994$, and 2013)

\section{Fires, climate, and tree establishment patterns}

In stands dominated by $A$. religiosa, we found a continuous pattern of tree establishment. There was a pulse of higher regeneration in 1949 and 1950, which coincided with a slight increase in precipitation, but it was not associated with fires (Fig. 6a). In codominated sites, we also detected a continuous pattern of tree regeneration that was not associated with fires. Between 1963 and 1976, regeneration appears to have responded positively to precipitation, but not to fires (Fig. 6b). Finally, establishment was also continuous in sites dominated by $P$. pseudostrobus, where we could not associate regeneration peaks with either the occurrence of fires or with precipitation (Fig. 6c).

\section{Discussion}

Fire regimes in the MBBR did not differ among forests dominated by $A$. religiosa, $P$. pseudostrobus, or codominated by both species. The current fire regimes in these forests can be characterized by frequent, low-extent fires, with greater occurrence during the dry season. This contrasts with our hypothesis in which we expected that forests dominated by $A$. religiosa experienced infrequent 
Table 4 Fire scar seasonality in the MBBR for the period 1920 to 2015, where D = dormancy, EE = early earlywood, ME = middle earlywood, $\mathrm{LE}=$ late earlywood, $\mathrm{L}=$ latewood, dry season fires $=\mathrm{EE}+\mathrm{ME}$, and wet season fires $=\mathrm{LE}$

\begin{tabular}{|c|c|c|c|c|c|c|c|c|}
\hline Forest & Identifiable season & $\mathrm{D}$ & $\mathrm{EE}$ & ME & LE & $\mathrm{LW}$ & Dry season fire scars & Wet season fire scars \\
\hline \multicolumn{9}{|l|}{ Fir } \\
\hline Number & 107 & 0 & 19 & 70 & 18 & 0 & 89 & 18 \\
\hline Percentage & 100 & 0 & 17.7 & 65.4 & 16.9 & 0 & 83.1 & 16.9 \\
\hline \multicolumn{9}{|l|}{ Pine-fir } \\
\hline Number & 124 & 0 & 15 & 90 & 19 & 0 & 105 & 19 \\
\hline Percentage & 100 & 0 & 12.1 & 72.5 & 15.4 & 0 & 84.6 & 15.4 \\
\hline \multicolumn{9}{|l|}{ Pine } \\
\hline Number & 84 & 0 & 4 & 74 & 6 & 0 & 78 & 6 \\
\hline Percentage & 100 & 0 & 4.7 & 88.1 & 7.2 & 0 & 92.8 & 7.2 \\
\hline \multicolumn{9}{|l|}{ All forests } \\
\hline Number & 315 & 0 & 38 & 234 & 43 & 0 & 272 & 43 \\
\hline Percentage & 100 & 0 & 12.6 & 72.4 & 15 & 0 & 86.3 & 13.7 \\
\hline
\end{tabular}

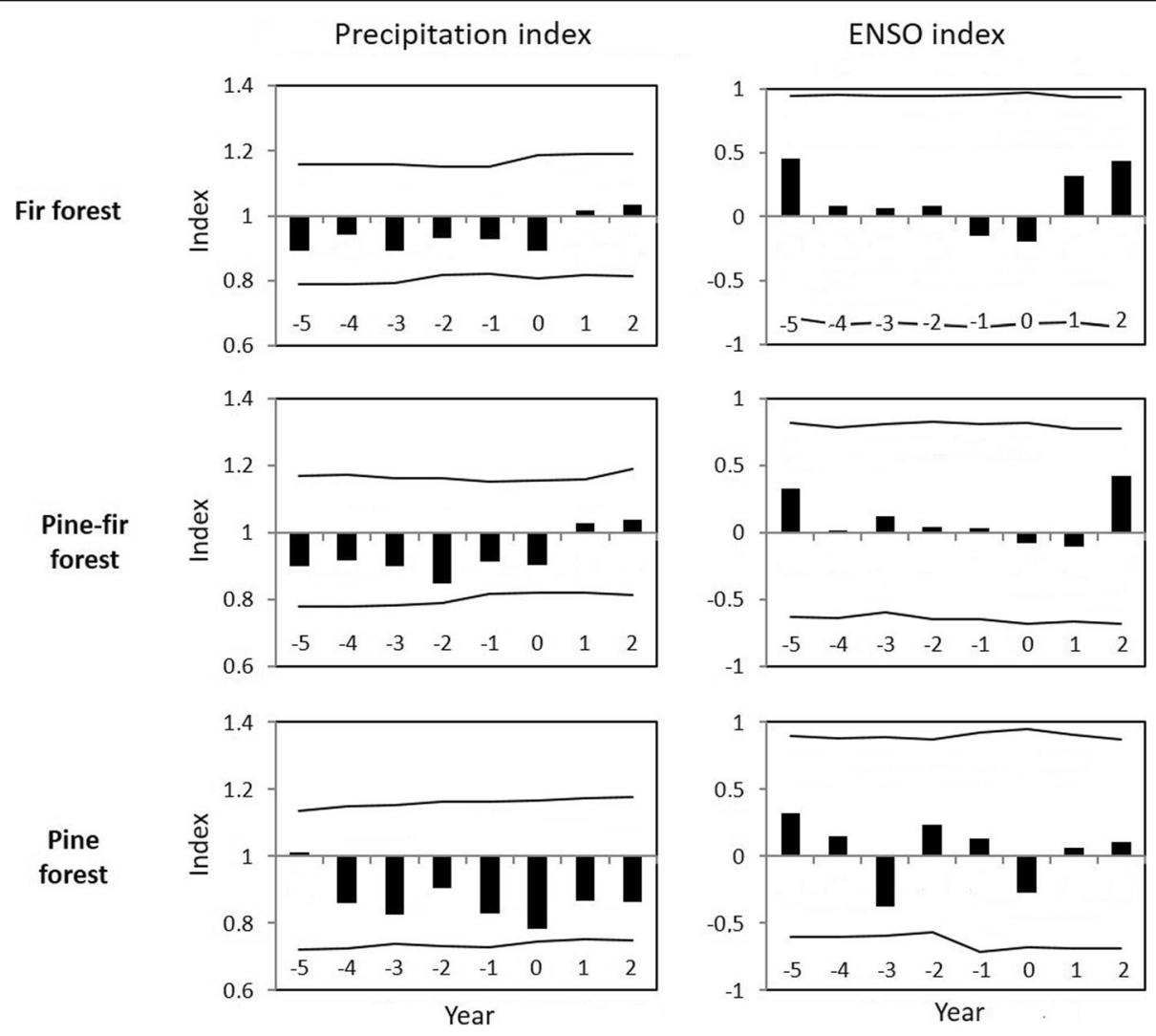

Fig. 5 Superposed epoch analysis for the relationship between local precipitation (tree-ring width index; left panels), ENSO index (right panels), and fire occurrence, for the period 1925 to 2015, in fir forest (sites dominated by A. religiosa), mixed pine-fir forest (sites codominated by both $P$. pseudostrobus and A. religiosa), and pine forest (sites dominated by P. pseudostrobus), for fire scars recorded in $>25 \%$ of scarred trees in the Monarch Butterfly Biosphere Reserve, Mexico. Values above the mean (index $=1$ ) represent wet years, while values below the mean represent dry years. ENSO values above the mean (index $=0$ ) represent La Niña conditions, while ENSO values below the mean represent El Niño conditions. Precipitation and ENSO values represent climate conditions during the fire year (0), the 5 years preceding fires, and the 2 years after fires. The lines above and under the $x$-axes correspond to the $95 \%$ confidence intervals 


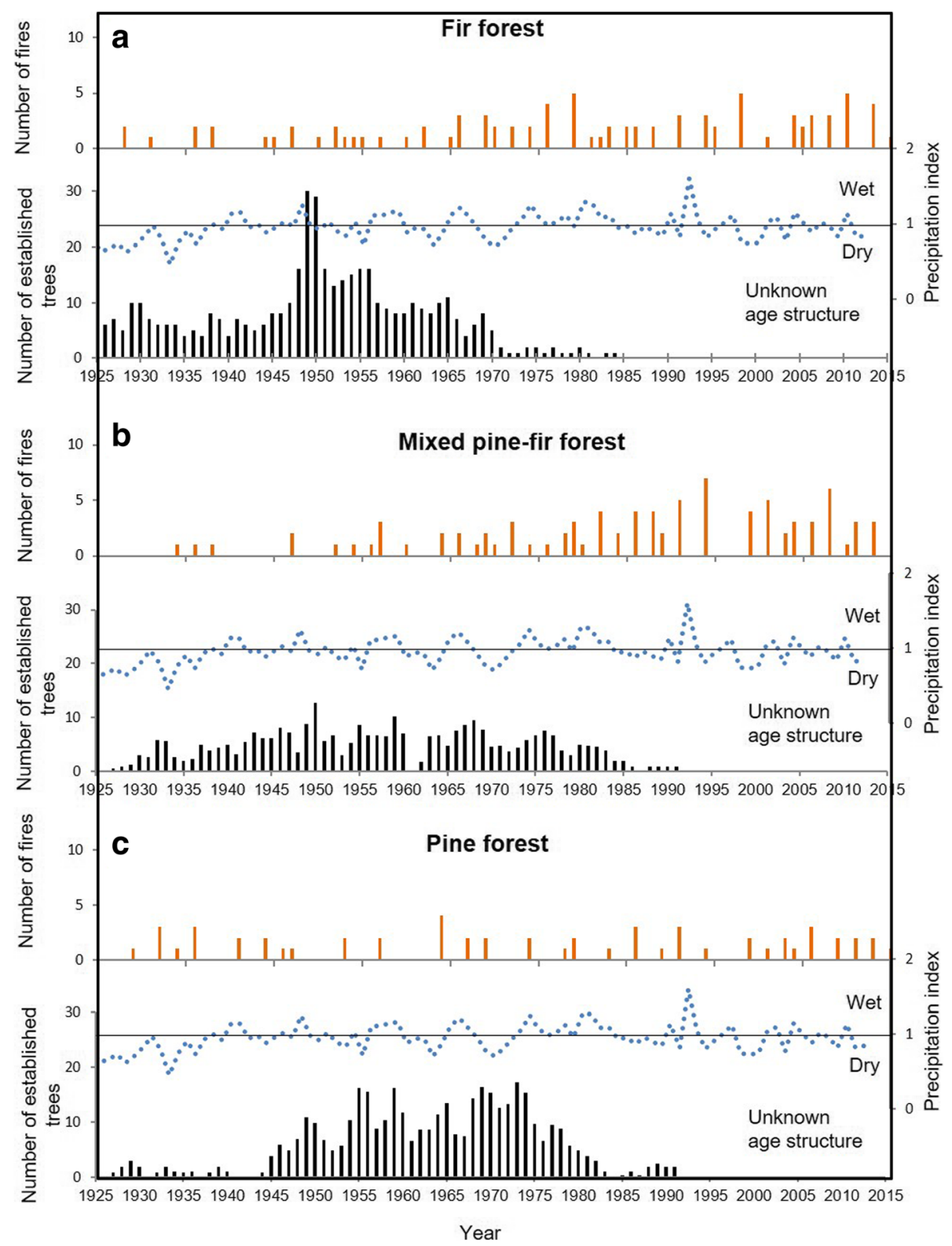

Fig. 6 Number of fires (orange bars), tree-ring width index as a proxy of rainfall (dotted line), and tree establishment (black bars) in (a) fir forest (sites dominated by A. religiosa), (b) mixed pine-fir forest (sites codominated by both P. pseudostrobus and A. religiosa), and (c) pine forest (sites dominated by P. pseudostrobus), in the Monarch Butterfly Biosphere Reserve, Mexico, as of 2015. Tree-ring width values above the continous black line (mean =1) indicate wet conditions, and below indicate dry conditions. After 1990, age structure is unknown because only trees with diameter $\geq 25 \mathrm{~cm}$ at $1.3 \mathrm{~m}$ height were sampled at the time of data collection

fires. In addition, our results indicated that neither climate nor ENSO strongly determined the presence of fires in the coniferous forests of the reserve.

Fire regimes can be explained by large-scale, top-down controlling factors, such as climate variability and global circulation phenomena, and by local-scale, bottom-up controlling factors, like primary productivity, availability of dry fuels, sources of ignition, and legacies of forest management (Yocom et al. 2010). In our study, these climatic and local factors appeared to be similar among pine, mixed pine-fir, and fir forests. High fire frequency can be explained by the presence of plentiful sources of ignition, such as agricultural burns, promotion of pasture for livestock grazing, weed control, and extraction of non-timber products (Martínez-Torres et al. 2016), that could have triggered more fires and reduced fuel load accumulation, reducing the probability of moderate-severity fires, particularly in mixed pine-fir and fir forests (Mallek et al. 2013). It is also likely that the occurrence of frequent, low-extent fires is associated with effective control and suppression 
of fires (Cantú-Fernández 2013), strategies followed to reduce the extent of fires, which do not differ among the different vegetation types in the MBRR (MartínezTorres et al. 2015).

Fuel availability can also be explained by climate patterns. In this region, $78 \%$ of rainfall occurs from July to October, which means that, during the rest of the year, fuels could reach the conditions that allow fire spread (McKenzie 2004). Previous research has found no relationship between severity of droughts and fire frequency in central Mexico (Pompa-García et al. 2017), which is consistent with our findings. It confirms that fires in the MBBR occur when rainfall is just below the annual average, and their incidence is not strongly related to severe drought and ENSO fluctuations. It is interesting that, during 1983 and 1998 (ENSO years), there was no considerable increase in fires in the MBBR, which coincides with observed fires in the highest Mexican mountain, Pico de Orizaba (Yocom and Fulé 2012), but contrasts with the atypical increases of fires in the rest of central, southern, and northern Mexico (Rodríguez-Trejo and Pyne 1999; Yocom et al. 2010).

Tree establishment in the three forest types was not associated with fires. This contrasts sharply with the synchrony between tree establishment and fire frequency found in coniferous forests in northern Mexico (Fulé and Covington 1997; Poulos et al. 2013). There are no indications that forests dominated by $A$. religiosa require high-magintude fires to promote regeneration but, rather, their regeneration is mediated by frequent low-severity fires, just as observed in the lower elevation pine-dominated forest. In addition, the age structure for all three forest types was continuous, which indicated that they were populations in continuous regeneration, so there was a continuous supply of biomass (Margolis et al. 2007). These factors imply that small-scale disturbances, such as frequent, low-extent fires, create gaps with sufficient light and size conditions to promote tree establishment (Frelich 2002). In fact, the recruitment of $A$. religiosa seedlings is greater in canopy clearings associated with small-scale disturbances, such as selective logging, fuelwood collection, and thinning, than in the forest understory (Ángeles-Cervantes and López-Mata 2009; Guerrero-Vizcaíno 2016). Our results also suggest that tree recruitment in the MBRR apparently is independent from fire, since neither $A$. religiosa nor $P$. pseudostrobus tree establishment is associated with cyclic fires.

It is important to point out that short fire return intervals have been documented in high-elevation mountain coniferous forests of northern (Yocom et al. 2017) and central Mexico (Ortega-Jiménez 2012; Yocom and Fulé 2012; Cerano-Paredes et al. 2016). Furthermore, a latitudinal gradient in the range of fire return intervals has been proposed, with lower intervals in tropical areas
(SCF 2001; Sommers et al. 2011). Thus, this fire regime could be a common condition of coniferous forests in subtropical and tropical latitudes, where the contrast in the annual seasonality of temperature and precipitation is of lesser magnitude than in boreal or austral forests (García 2003). In fact, there are indications that fuel load dynamics (production, decay) is faster than in high-latitude forests (Quintero-Gradilla et al. 2015). Growth rates and population dynamics of tropical conifers also appear to be faster (Klepac 2001; Myers and Rodríguez-Trejo 2009). In fact, dendrochronological studies confirm that some tropical conifers barely reach 150 years of age, such as Pinus teocote Schiede. ex Schltdl. \& Cham. (López-Sánchez et al. 2017) and Pinus oocarpa Schiede ex Schetol (VillanuevaDíaz et al. 2018). Hence, trees in the MBBR could be young (less than 120 years of age), in part due to rapid population replacement. The absence of ancient stumps, which would have otherwise helped expand our chronology, might be also associated with a fast rate of decay (Cassell 2012). Therefore, frequent fire could be a consequence of continuous biomass supply and a fast fuel load replacement that hinders its accumulation (Sah et al. 2006).

Although the biogeographic aspect can be a determining factor in fire regimes in tropical coniferous forests, it has also been suggested that fire regimes in these ecosystems are mostly associated with human activity, given the long history of management that these forests have experienced (Myers and Rodríguez-Trejo 2009; Pompa-García et al. 2017). The MBBR is not an exception, since it has been an important timber supply area for central Mexico since the twentieth century, especially for forestry and mining industries (Ibarra-García 2011), including fir forests, currently protected for the monarch butterfly migration. In fact, we did not observe any changes in fire frequency, neither after 1986 when the fir stands surrounding monarch butterfly colonies were protected, nor after 2000 when the reserve obtained its current extent. This contrasts with other natural protected areas in Mexico, such as Pico de Orizaba (Yocom and Fulé 2012), Sierra de Manantlán (Cerano-Paredes et al. 2015), or in areas dedicated to forestry, such as the Sierra de Oaxaca (Ortega-Jiménez 2012), where a decrease in the number of fires has been observed. Another indication that disturbance regimes have been altered is the absence of long-lived trees, which can be explained by the fact that trees with larger dimensions have been extracted in the MBBR (Murillo-García 2009).

Unfortunately, the absence of natural and human disturbance records in the MBBR, and the fact that our fire chronology is no longer than 100 years, do not allow us to detect a fire regime disruption. However, we suggest that natural fire regimes in coniferous forests of the MBBR have been altered. Montane tropical coniferous forests share genetic, structural, and functional attributes 
with forests of higher latitudes (Aguirre-Planter et al. 2012; Aguirre-Gutiérrez et al. 2014). Therefore natural fire regimes in Mexican coniferous forests could share some attributes with those reported for higher-latitude forests (Rodríguez-Trejo and Fulé 2003). Due to the long-standing practice of forest management in Mexico and particularly in the MBBR, it is likely that human disturbances, such as logging, fire management, and firewood collection, have limited the occurrence of high-magnitude fires, especially in fir forests. In addition, the frequent fuel consumption and the continuous extraction of wood biomass allow the opening of clearings with sufficient light conditions to promote tree establishment. These findings suggest that forest management and active fire suppression have replaced the role of fire as the main disturbance that mediates regeneration of the coniferous forests of the MBBR (Pérez-Salicrup et al. 2016).

Fire regimes are not static (Sommers et al. 2011), but their alteration by human activities can exacerbate their impact on forest communities (Buma 2015). On one hand, an increase in the frequency of fires can limit the establishment of species adapted to infrequent fires, such as $A$. religiosa, which has already been reported in the Nevado de Toluca (Endara-Agramont et al. 2012). On the other hand, fire suppression, a policy widely adopted in the MBBR (Cantú-Fernández 2013), could generate an atypical accumulation of fuels, thereby increasing the probability of stand-replacing fires, which in turn could be particularly critical in A. religiosa-dominated stands where the monarch butterfly hibernates (Keiman and Franco 2004). In addition, as seen in other conifer forests (Calder and St. Clair 2012), reduction in the fire return interval could generate the gradual replacement of populations, in this case, of $A$. religiosa by $P$. pseudostrobus, particularly in stands codominated by both species. Climate change could also generate an elevational effect, as described above (Sáenz-Romero et al. 2012), as well as changes in the availability and moisture of fuels (Sommers et al. 2011). Changes in fire regimes could lead forests to alternative stable states (Scheffer et al. 2001), altering vegetation structure, post-fire succession patterns, stand density, spatial heterogeneity, and physiognomy (Mallek et al. 2013).

Unfortunately, there is little information on fire regimes and their effect on natural regeneration in tropical coniferous forests, where ecological conditions differ considerably from those of boreal or austral regions (Myers and Rodríguez-Trejo 2009). In addition, the effects of fire suppression in ecosystems adapted to frequent and low-severity and low-intensity fires are fully documented (Sherriff and Veblen 2006; Marlon et al. 2012; Lafon et al. 2017), but we have little information to project the long-term effects of increased fire frequency in coniferous forests in the tropics. Hence, it is difficult to provide advice on fire management or on the reintroduction of fire, especially in the mixed $P$. pseudostrobus $-A$ religiosa-codominated stands. In the case of our study locations, human activities appear to be the most important factor in limiting the occurrence of large-scale disturbances, while, through management actions, still allowing the continuous regeneration of these conifers over time.

Finally, to have a more solid frame of reference in decision making for forest management, it is necessary to document the history of natural and human disturbances, including their synergies, at least in recent decades. A better understanding of disturbance regimes is fundamental to preserving the long-term integrity of the forest where monarch butterflies hibernate. Likewise, it is important to reconstruct and evaluate fire regimes, particularly in other locations of montane tropical coniferous forests in Mexico, considering the current context of global change (Gauthier et al. 2015).

\section{Conclusions}

The reconstruction of the history of fires in the MBBR revealed that the forests dominated by $P$. pseudostrobus, A. religiosa, or codominated by both species experienced frequent, low-severity, and low-extent fires, which took place mostly during the dry season. The occurrence of fires was weakly associated with the presence of low rainfall and climatic events, such as El Niño years. There was no relationship between the patterns of establishment of A. religiosa and $P$. pseudostrobus individuals with fire occurrence, which suggests that the regeneration of both species does not currently depend on cyclic fires but is associated with the frequency of other natural or human-driven disturbances.

We suggest that fire regimes have been altered by human activities, particularly logging, which have likely modified fuel loads, sources of ignitions, and regeneration patterns that directly affect the frequency, severity, and extent of fires. These human disturbances may have replaced the role of fire to trigger regeneration of $A$. religiosa and $P$. pseudostrobus. More research is needed on fire regimes in other tropical coniferous forests, and it is critical to further evaluate the effect of natural and human disturbances, as well as their synergies, on the regeneration of coniferous species.

\footnotetext{
Acknowledgements

The first author thanks the academic support of the Graduate Program in Biological Sciences at Universidad Nacional Autónoma de México, and the National Council of Science and Technology (CONACyT, Mexico) through the scholarship received during his $\mathrm{PhD}$ studies. This paper is a partial requirement for the first author to obtain a Doctor in Sciences degree. Both authors appreciate the facilities to conduct fieldwork by the Mexican

Secretariat of Environment and Natural Resources (SEMARNAT), the National Commission of Natural Protected Areas (CONANP), the Monarch Butterfly Biosphere Reserve Office and the authorities of ejidos Chincua, Jesús Nazareno, Santa Ana, El Rosario, El Paso, Vare Chiquichuca, and indigenous communities Donaciano Ojeda and Crescencio Morales. Special thanks to J.
} 
Trinidad Sáenz, Á. González, D. González, L. Lara, and I. Cabrera, who collaborated in the fieldwork; and to the Eco-garden at the Instituto de Investigaciones en Ecosistemas y Sustentabilidad-UNAM for its support during the drying and polishing of cross-sections. We also thank B. Cassell for English corrections.

\section{Funding}

This research was funded by the projects SEP-CONACYT 2010-154434 "Effect of natural and human disturbances in coniferous forest of the Monarch Butterfly Biosphere Reserve: implications for fire management," and PAPIIT-UNAM IN209716 "Sinergy of human and natural disturbances in montane forests of eastern Michoacán". Research was also supported by the PASDA-DGAPA UNAM program.

\section{Availability of data and materials}

The datasets used and/or analyzed during the current study are available from the corresponding author on reasonable request.

\section{Authors' contributions}

Both authors contributed with literature review, sampling, data analyses and writing of this document.

\section{Ethics approval and consent to participate}

Not applicable.

\section{Consent for publication}

Not applicable.

\section{Competing interests}

The authors declare that they have no competing interests.

\section{Publisher's Note}

Springer Nature remains neutral with regard to jurisdictional claims in published maps and institutional affiliations.

\section{Author details}

${ }^{1}$ Posgrado en Ciencias Biológicas, Universidad Nacional Autónoma de México, Circuito de Posgrados, Ciudad Universitaria, Coyoacán, Ciudad de México 04510, México. ${ }^{2}$ Instituto de Investigaciones en Ecosistemas y Sustentabilidad, Universidad Nacional Autónoma de México, 8701 Antigua Carretera a Pátzcuaro, Exhacienda de San José de la Huerta, Morelia, Michoacán 58190, México.

Received: 9 October 2018 Accepted: 6 March 2019

Published online: 06 June 2019

\section{References}

Abrams, M.D., and D.A. Orwig. 1996. A 300-year history of disturbance and canopy recruitment for co-occurring white pine and hemlock on the Allegheny Plateau, USA. Journal of Ecology 84 (3): 353-363. https://doi. org/10.2307/2261198.

Agee, J.K. 1993. Methods of evaluating forest fire history. Journal of Northeast Forestry University 4 (2): 1-10. https://doi.org/10.1007/BF02843067.

Aguirre-Gutiérrez, J., H.M. Serna-Chavez, A.R. Villalobos-Arámbula, J.A. Pérez de la Rosa, and N. Raes. 2014. Similar but not equivalent: ecological niche comparison across closely-related Mexican white pines. Biodiversity and Distributions 21: 245-257. https://doi.org/10.1111/ddi.12268.

Aguirre-Planter, E., J.P. Jaramillo-Correa, S. Gómez-Acevedo, D.P. Khasa, J. Bousquet, and L.E. Eguiarte. 2012. Phylogeny, diversification rates and species boundaries of Mesoamerican firs (Abies, Pinaceae) in a genuswide context. Molecular Phylogenetics and Evolution 62: 263-274. https:// doi.org/10.1016/j.ympev.2011.09.021.

Ángeles-Cervantes, E., and L. López-Mata. 2009. Supervivencia de una cohorte de plántulas de Abies religiosa bajo diferentes condiciones post-incendio. Boletín de la Sociedad Botánica de México 84: 25-33. [In Spanish.]

Ávila-Bello, C.H., L. López-Mata, M.C. Mandujano. 2015. Ecología poblacional de Abies hickelii (Flous et Gaussen) en el Pico de Orizaba, Veracruz, México. In Ecología, biología y conservación del género Abies en México: estudios de Abies en México. Edited by M. del Rosario Pineda-López, R.L. Sánchez-Velázquez, and J.C. NoaCarranza. Pages 21-42. Saarbrücken, Germany: Editorial Académica Española. [In Spanish.]
Baker, W.I., and A.J. Dugan. 2013. Fire history implications of fire-scarring. Canadian Journal of Forest Research 43: 951-962. https://doi.org/10.1139/cjfr-2013-0176.

Bergeron, Y. 1998. Les conséquences des changements climatiques sur la fréquence des feux et la composition forestière au sud-ouest de la forêt boréale québécoise. Géographie Physique e Quaternaire 52 (2): 1-13. https:// doi.org/10.7202/004768ar [In French.].

Brewer, P.W., M.E. Velázquez, E.K. Sutherland, D.A. Falk. 2016. Fire History Analysis and Exploration System (FHAES) version 2.0.2. https://www.frames.gov/fhaes/home. Accessed 3 May 2016

Brower, L.P., D.A. Slayback, P. Jaramillo-López, I. Ramirez, K.S. Oberhauser, E.H. Williams, and L.S. Fink. 2016. Illegal logging of 10 hectares of forest in the Sierra Chincua monarch butterfly overwintering area in Mexico. American Entomologist 62 (2): 92-97. https://doi.org/10.1093/ae/tmw040.

Brower, L.P., E.H. Williams, P. Jaramillo-López, D.R. Kust, D.A. Slayback, and M.I. Ramirez. 2017. Butterfly mortality and salvage logging from the March 2016 storm in the Monarch Butterfly Biosphere Reserve in Mexico. American Entomologist 63 (3): 151-164. https://doi.org/10.1093/ae/tmx052.

Brown, P. 2006. Climate effects on fire regimes and tree recruitment in Black Hills ponderosa pine forests. Ecology 87 (10): 2500-2510. https://doi.org/10.1890/ 0012-9658(2006)87[2500:CEOFRA]2.0.CO;2.

Brown, P., and B. Cook. 2006. Early settlement forest structure in Black Hills ponderosa pine forests. Forest Ecology and Management 223: 284-290. https://doi.org/10.1016/j.foreco.2005.11.008.

Buma, B. 2015. Disturbance interactions: characterization, prediction, and the potential for cascading effects. Ecosphere 6 (4): 1-15. https://doi.org/10.1890/ES15-00058.1.

Calder, W.J., and S.B. St. Clair. 2012. Facilitation drives mortality patterns along succession of aspen-conifer forests. Ecosphere 3 (6): 1-11. https://doi.org/10. 1890/ES12-00119.1.

Camarillo-Luna, A.R. 2018. Plaga forestal por escarabajos descortezadores y el marco legal para su control: el caso de la Reserva de la Biosfera Mariposa Monarca. Dissertation, Universidad Nacional Autónoma de México, Morelia, Michoacán, Mexico. [In Spanish.]

Cantú-Fernández, M. 2013. Incendios de 2012 en la Reserva de la Biosfera Mariposa Monarca: caracterización y respuesta institucional. Dissertation, Universidad Nacional Autónoma de México, Morelia, Michoacán, Mexico. [In Spanish.]

Carlón-Allende, T., M.E. Mendoza-Cantú, J. Villanueva-Díaz, and A. Lara. 2016. Climatic responses of Pinus pseudostrobus and Abies religiosa in the Monarch Butterfly Biosphere Reserve, central Mexico. Dendrochronologia 38: 103-116. https://doi.org/10.1016/j.dendro.2016.04.002.

Carlón-Allende, T., J. Villanueva-Díaz, M.E. Mendoza, and D.R. Pérez-Salicrup. 2018 Climatic signal in earlywood and latewood in conifer forests in the Monarch Butterfly Biosphere Reserve, Mexico. Tree-Ring Research 74 (1): 63-75. https:// doi.org/10.3959/1536-1098-74.1.63.

Cassell, B.A. 2012. Fire history of the Sierra de Manantlán Biosphere Reserve in western Mexico. Dissertation, University of Washington, Seattle, Washington, USA.

Cerano-Paredes, J., J. Villanueva-Díaz, R. Cervantes-Martínez, P. Fulé, L. Yocom, G. Esquivel-Arriaga, and E. Jardel-Peláez. 2015. Historia de incendios en un bosque de pino de la sierra de Manantlán, México. Bosque 36(1): 41-52. [In Spanish.] https://doi.org/10.4067/S0717-92002015000100005.

Cerano-Paredes, J., J. Villanueva-Díaz, L. Vázquez-Selem, R. Cervantes-Martínez, G. Esquivel-Arriaga, V. Guerra de la Cruz, and P.Z. Fulé. 2016. Régimen histórico de incendios y su relación con el clima en un bosque de Pinus hartwegii al norte del estado de Puebla, México. Bosque 37 (2): 389-399. [In Spanish.] https://doi.org/10.4067/S0717-92002016000200017.

CONANP [Comisión Nacional de Áreas Naturales Protegidas]. 2001. Programa de manejo de la Reserva de la Biosfera Mariposa Monarca. Coyoacán, México City: Secretaría de Medio Ambiente y Recursos Naturales. [In Spanish.].

Cook, E.R. 2000. Niño 3 Index Reconstruction. International Tree-Ring Data Bank. IGBP PAGES/World Data Center-A for Paleoclimatology Data Contribution Series Number 2000-052. NOAA/NGDC Paleoclimatology Program, Boulder, Colorado, USA. <ftp://ftp.ncdc.noaa.gov/pub/data/paleo/treering/ reconstructions/nino3_recon.txt>. Accessed 22 Mar 2017.

Cornejo-Tenorio, G., and G. Ibarra-Manríquez. 2017. Flora of the core zones of the Monarch Butterfly Biosphere Reserve, Mexico: composition, geographical affinities and beta diversity. Botanical Sciences 95 (1): 103-129. https://doi.org/ $10.17129 /$ botsci.803.

Davies, G.M. 2013. Understanding fire regimes and the ecological effects of fire. In Fire phenomena and the Earth system: an interdisciplinary guide to fire science. Edited by C.M. Belcher. Pages 97-124. Chichester England, United Kingdom: John Wiley and Sons. 
Endara-Agramont, A., S. Franco-Maass, G. Nava-Bernal, J. Valdez-Hernández, and T. Fredericksen. 2012. Human disturbance on the structure and regeneration of forests in the Nevado de Toluca National Park, Mexico. Journal of Forestry Research 23 (1): 39-44. https://doi.org/10.1007/s11676-012-0226-8.

Franklin, J., D. Berg-Rae, D.A. Thornburgh, and J.C. Tappeiner. 1997. Alternative silvicultural approaches to timber harvesting: variable retention harvest systems. In Creating a forestry for the 21st century: the science of ecosystem management. Edited by K.A. Kohm and J.F. Franklin. Pages 111-138. Washington, D.C., USA: Island Press.

Frelich, L.E. 2002. Forest dynamics and disturbance regimes: studies from temperateevergreen deciduous forests. Cambridge England, United Kingdom: Cambridge University Press. https://doi.org/10.1017/CBO9780511542046.

Fulé, P., J. Crouse, T. Heinlein, M. Moore, W. Covington, and G. Verkamp. 2003. Mixed severity fire regime in a high elevation forest of Grand Canyon, Arizona, USA. Landscape Ecology 18: 465-486 https://doi.org/10.1023/A:1026012118011.

Fulé, P., J. Villanueva-Díaz, and M. Ramos. 2005. Fire regime in a conservation reserve in Chihuahua, Mexico. Canadian Journal for Forest Research 35: 320 330. https://doi.org/10.1139/x04-173.

Fulé, P., L. Yocom, C. Cortés-Montaño, D. Falk, J. Cerano-Paredes, and J. VillanuevaDíaz. 2012. Testing a pyroclimatic hypothesis on the Mexico-United States border. Ecology 93 (8): 1830-1840. https://doi.org/10.1890/11-1991.1.

Fulé, P.Z., and W. Covington. 1997. Fire regimes and forest structure in the Sierra Madre Occidental, Durango, Mexico. Acta Botánica Mexicana 41: 43-47. https://doi.org/10.21829/abm41.1997.791.

Fulé, P.Z., J.E. Korb, and R. Wu. 2009. Changes in forest structure in a mixed conifer forests, southwestern Colorado, USA. Forest Ecology and Management 258: 1200-1210. https://doi.org/10.1016/j.foreco.2009.06.015.

Fulé, P.Z., and D.C. Laughlin. 2007. Wildland fire effects on forest structure over an altitudinal gradient, Grand Canyon National Park, USA. Journal of Applied Ecology 44: 136-146. https://doi.org/10.1111/j.1365-2664.2006.01254.x.

Gama-Orozco, J.L. 2009. Estructura y dinámica poblacional de Pinus montezumae Lamb. en un bosque de la zona de Milpa Alta, D. F. Dissertation, Instituto Politécnico Nacional, Mexico City, Mexico. [In Spanish.]

García, E. 1997. Climatología de la zona de hibernación de la mariposa monarca en la Sierra Transvolcánica de México, invierno 1991-1992. Serie Varia 1 (16): 5-26. [In Spanish.].

García, E. 2003. Distribución de la precipitación en la República Mexicana. Investigaciones Geográficas 50: 67-76. [In Spanish.].

Gauthier, S., P. Bernier, T. Kuuluvainen, A.Z. Shvidenko, and D.G. Schepaschenko. 2015. Boreal forest health and global change. Science 349 (6250): 819-822. https://doi.org/10.1126/science.aaa9092.

Gill, L., and A.H. Taylor. 2009. Top-down and bottom-up controls on fire regimes along an elevational gradient on the east slope of the Sierra Nevada, California, USA. Fire Ecology 5 (3): 57-75. https://doi.org/10.4996/ fireecology.0503057.

Grissino-Mayer, H. 1999. Modeling fire interval data from the American Southwest with the Weibull distribution. International Journal of Wildland Fire 9 (1): $37-$ 50. https://doi.org/10.1071/WF99004.

Grissino-Mayer, H. 2001. FHX2 — software for analyzing temporal and spatial patterns in fire regimes from tree rings. Tree-Ring Research 57 (1): 115-124.

Guerrero-Vizcaíno, C. 2016. Regeneración de Abies religiosa en la Reserva de la Biosfera Mariposa Monarca. Dissertation, Universidad Nacional Autónoma de México, Morelia, Michoacán, Mexico. [In Spanish.]

Gugger, P., A. González, H. Rodríguez, S. Sugita, and J. Cavender. 2013. Southward Pleistocene migration of Douglas-fir into Mexico: phylogeography, ecological niche modeling, and conservation of 'rear edge' populations. New Phytologist 189: 1185-1199. https://doi.org/10.1111/j.1469-8137.2010.03559.x.

Gutsell, S.L., and E.A. Johnson. 1996. How fire scars are formed: coupling a disturbance process to its ecological effect. Canadian Journal of Forest Research 26: 166-174. https://doi.org/10.1139/x26-020.

Heyerdahl, E.K., and E. Alvarado. 2003. Influence of climate and land use on historical surface fires in pine-oak forests, Sierra Madre Occidental, Mexico. In Fire and climatic change in temperate ecosystems of the western Americas. Edited by T. Veblen, W.L. Baker, G. Montenegro, and T.W. Swetnam. Pages 196-217. New York, New York, USA: Springer-Verlag.

Heyerdahl, E.K., P.M. Brown, S.G. Kitchen, and M.H. Weber. 2011. Multicentury fire and forest histories at 19 sites in Utah and eastern Nevada. USDA Forest Service General Technical Report RMRS-GTR-261. Fort Collins, USA: USDA Forest Service, Rocky Mountain Research Station.

Holdrige, L.R. 1947. Determination of world plant formation from simple climatic data. Science 105: 367-368.
Honey-Róses, J. 2009. Illegal logging in common property forests. Society \& Natural Resources 22 (10): 916-930. https:/doi.org/10.1080/08941920903131120.

Ibarra-García, M.V. 2011. Conformación del espacio social de los bosques del ejido del Rosario, Michoacán, 1938-2010. Investigaciones Geográficas 75: 75 87 [In Spanish.].

INEGI [Instituto Nacional de Estadística, Geografía e Informática]. 2010. Censo de población y vivienda 2010, principales resultados por localidad. http://www. beta.inegi.org.mx/programas/ccpv/2010/default.html\#Microdatos. Accessed 15 Oct 2017

Johnson, E.A., and G.l. Fryer. 1989. Population dynamics in lodgepole pine-Engelmann spruce forests. Ecology 70 (5): 1335-1345. https://doi.org/10.2307/1938193.

Keiman, A., and M. Franco. 2004. Can't see the forest for the butterflies: the need for understanding forest dynamics at monarch overwintering sites. In The monarch butterfly, biology and conservation. Edited by K. Oberhauser and M.J. Solensky. Pages 135-140. New York, New York, USA: Cornell University Press.

Klepac, D. 2001. Research on diameter growth and increment of some Mexican pines. Acta Botanica Croatica 60 (2): 267-276

Krebs, P., G.B. Pezzatti, S. Mazzoleni, L.M. Talbot, and M. Conedera. 2010. Fire regime: history and definition in disturbance ecology. Theory in Biosciences 129: 53-69. https://doi.org/10.1007/s12064-010-0082-z.

Kulakowski, D., and D. Jarvis. 2011. The influence of mountain pine beetle outbreaks and drought on severe wildfires in northwestern Colorado and southern Wyoming: a look at the past century. Forest Ecology and Management 262: 1686-1696. https://doi.org/10.1073/pnas.1411346111.

Lafon, C.W., A.T. Naiton, H.D. Grissino-Mayer, S.P. Horn, and T.A. Waldrop. 2017. Fire history of the Appalachian region: a review and synthesis. USDA Forest Service General Technical Report SRS-219. Asheville, North Carolina, USA: USDA Forest Service, Southern Research Station.

Lethonen, H., P. Huttunen, and P. Zetterberg. 1996. Influence of man on forest fire frequency in North Karelia, Finland, as evidenced by fire scars on Scots pines. Annales Botanici Fennici 33: 257-263.

López-Sánchez, J.A., J. Méndez-González, A. Zermeño-González, J. Cerano-Paredes, and M. García-Aranda. 2017. Impacto de descortezadores en el incremento radial de Pinus teocote Schiede ex Schltdl. \& Cham. y Pseudotsuga menziesii (Mirb.) Franco. Revista Mexicana de Ciencias Forestales 8 (41): 82-108. [In Spanish.] https://doi.org/10.29298/rmcf.v8i41.27.

Mallek, C., H. Safford, J. Viers, and J. Miller. 2013. Modern departures in fire severity and area vary by forest type in Sierra Nevada and southern Cascades, California. Ecosphere 4 (12): 153. https:/doi.org/10.1890/ES13-00217.1.

Margolis, E.Q., T.W. Swetnam, and C.D. Allen. 2007. A stand-replacing fire history in upper montane forests of the southern Rocky Mountains. Canadian Journal of Forest Research 37: 2227-2241. https://doi.org/10.1139/X07-079.

Marlon, J.R., P.J. Bartlein, D.G. Gavin, C.J. Long, R.S. Anderson, C.E. Briles, K.J. Brown, D. Colombaroli, D.J. Hallett, M.J. Power, E.A. Scharf, and M.K. Walsh. 2012. Long-term perspectives on wildfires in the western USA. PNAS 109 (9): 535543. https://doi.org/10.1073/pnas.1112839109.

Martínez-Torres, H.L., M. Cantú-Fernández, M.I. Ramírez-Ramírez, and D.R. PérezSalicrup. 2015. Fires and fire management in the Monarch Butterfly Biosphere Reserve. In Monarchs in a changing world. Edited by K. Oberhauser, K.R. Nail, and S. Altizer. Pages 179-189. New York, New York, USA: Cornell University Press.

Martínez-Torres, H.L., A. Castillo, M.I. Ramírez, and D.R. Pérez-Salicrup. 2016. The importance of the traditional fire knowledge system in a subtropical montane socio-ecosystem in a protected natural area. International Journal of Wildland Fire 25: 911-921. https://doi.org/10.1071/WF15181.

Mast, J., P. Fulé, M. Moore, W. Covington, and A. Waltz. 1999. Restoration of presettlement age structure of an Arizona ponderosa pine forest. Ecological Applications 9 (1): 228-239. https://doi.org/10.2307/2641181.

McKenzie, D. 2004. La historia del fuego y su relación con el clima. In Incendios forestales en México: métodos de evaluación. Edited by R.L. Villers and J.B. López. Pages 13-28. Coyoacán Mexico City, Mexico: Universidad Nacional Autónoma de México [In Spanish.]

Morett-Sánchez, J.C., and C. Cosío-Ruiz. 2017. Outlook of ejidos and agrarian communities in Mexico. Agricultura, Sociedad y Desarrollo 14 (1): 125-152. https://doi.org/10.22231/asyd.v14i1.526.

Murillo-García, A. 2009. El manejo forestal y sus implicaciones en la cubierta vegetal y en la estructura demográfica de especies comerciales: Reserva de la Biósfera de la Mariposa Monarca. Dissertation, Universidad Nacional Autónoma de México, Morelia, Michoacán, Mexico. [In Spanish.]

Myers, R.L., and D.A. Rodríguez-Trejo. 2009. Fire in tropical pine ecosystems. In Tropical fire ecology. Edited by M.A. Cochrane. Pages 557-605. Berlin, Germany: Springer https://doi.org/10.1007/978-3-540-77381-8_20. 
Navarrete, J., I. Ramírez, and D.R. Pérez-Salicrup. 2011. Logging within protected areas: spatial evaluation of the Monarch Butterfly Biosphere Reserve, Mexico. Forest Ecology and Management 262: 645-654. https://doi.org/10.1016/j. foreco.2011.04.033.

NOAA [National Oceanic and Atmospheric Administration]. 2017. Southern Oscillation Index. <https://www.ncdc.noaa.gov/teleconnections/enso/ indicators/soi/>. Accessed 27 Mar 2017

Ortega-Jiménez, S. 2012. Reconstrucción histórica de incendios mediante anillos de crecimiento en los bosques de San Miguel Cajonos, Oaxaca, México. Dissertation, Universidad Austral de Chile, Valdivia, Los Ríos, Chile. [In Spanish.]

Pérez-Salicrup, D., M. Cantú-Fernández, T. Carlón-Allende, E. Garduño-Mendoza, P. Jaramillo-López, J.E. Sáenz-Ceja, and H.L. Martínez-Torres. 2016. Restauración de un proceso: el fuego en la Reserva de la Biosfera Mariposa Monarca en los estados de México y Michoacán. In Experiencias Mexicanas en restauración de ecosistemas, ed. E. Ceccón and C. Martínez-Garza, 215-234. Mexico City, Mexico: Comisión Nacional para el Uso y Conservación de la Biodiversidad. [In Spanish.].

Pompa-García, M., J.J. Camarero, D.A. Rodríguez-Trejo, and D.J. Vega-Nieva. 2017. Drought and spatiotemporal variability of forest fires across Mexico. Chinese Geographical Sciences 8(1): 25-37. https://doi.org/10.1007/s11769-017-0928-0.

Poulos, H., J. Villanueva-Díaz, J. Cerano-Paredes, A. Camp, and R. Gatewood. 2013. Human influences on fire regimes and forest structure in the Chihuahuan Desert Borderlands. Forest Ecology and Management 298: 1-11. https://doi. org/10.1016/j.foreco.2013.02.014.

Pyne, S.J. 1996. World fire: the culture of fire on Earth. Seattle, Washington, USA: University of Washington Press.

Quintero-Gradilla, S.D., F. García-Oliva, R. Cuevas-Guzmán, E.J. Jardel-Peláez, and A. Martínez-Yrízar. 2015. Soil carbon and nutrient recovery after high-severity wildfire in Mexico. Fire Ecology 11 (3): 45-63. https://doi.org/10.4996/fireecology.1103045.

Ramírez-Ramírez, M.I. 2001. Cambios en las cubiertas de suelo en la Sierra de Angangueo, Michoacán y Estado de México, 1971-1994-2000. Investigaciones Geográficas 45: 39-55. [In Spanish.]

Rodríguez-Trejo, D., and P.Z. Fulé. 2003. Fire ecology of Mexican pines and a fire management proposal. International Journal of Wildland Fire 12: 23-37. https://doi.org/10.1071/WF02040.

Rodríguez-Trejo, D.A., and S.J. Pyne. 1999. Mexican fires of 1998. International Forest Fire News 20: 61-63.

Sáenz-Ceja, J.E. 2015. Reconstrucción dendrocronológica de la historia de establecimiento de Pinus pseudostrobus y Abies religiosa en la Reserva de la Biosfera Mariposa Monarca. Dissertation, Universidad Nacional Autónoma de México, Morelia, Michoacán, Mexico. [In Spanish.]

Sáenz-Ceja, J.E., and D.R. Pérez-Salicrup. 2019. The role of fire on regeneration of coniferous forests. Revista Chapingo Serie Ciencias Forestales y del Ambiente 25 (1): 123-139.

Sáenz-Romero, C., G. Rehfeldt, P. Duval, and R. Lindig. 2012. Abies religiosa habitat prediction in climatic change scenarios and implications for monarch butterfly conservation in Mexico. Forest Ecology and Management 275: 98106. https://doi.org/10.1016/j.foreco.2012.03.004

Sah, J.P., M.S. Ross, J.R. Snyder, S. Koptur, and H.C. Cooley. 2006. Fuel loads, fire regimes, and post-fire fuel dynamics in Florida Keys pine forests. International Journal of Wildland Fire 15: 463-478. https://doi.org/10.1071/WF05100.

Sánchez-González, A., L. López, and D. Granados. 2005. Semejanza florística entre los bosques de Abies religiosa de la Faja Volcánica Transmexicana. Investigaciones Geográficas 56: 62-76. [In Spanish.]

SCF [Service Canadien des Forêts]. 2001. Les feux de forêt: contexte du Programme scientifique du Service canadien des forêts. Ottawa, Ontario, Canada: SCF [In French.].

Scheffer, M., S. Carpenter, J.A. Foley, C. Folke, and B. Walker. 2001. Catastrophic shifts in ecosystems. Nature 413: 591-596. https://doi.org/10.1038/35098000.

Shawn, F., J. Bengt, J. Mari, and E. Per-Anders. 2008. Demographics and disturbance history of a boreal old growth Picea abies forest. Journal of Vegetation Science 19: 789-798. https://doi.org/10.3170/2008-8-18449.

Sherriff, R.L., and T.T. Veblen. 2006. Ecological effects of changes in fire regimes in Pinus ponderosa ecosystems in the Colorado Front Range. Journal of Vegetation Science 17 (6): 705-718.

Sommers, W.T., S.G. Coloff, and S. Conard. 2011. Synthesis of knowledge: fire history and climate change. Boise, Idaho, USA: George Mason University.

Speer, J. 2010. Fundamentals of tree-ring research. Tucson, Arizona, USA: The University of Arizona Press.

Vidal, O., J. López-García, and E. Rendón-Salinas. 2014. Trends in deforestation and forest degradation at a decade of monitoring in the Monarch Butterfly
Biosphere Reserve in Mexico. Conservation Biology 28 (1): 177-186. https:// doi.org/10.1111/cobi.12138.

Villanueva-Díaz, J., E.A. Rubio-Camacho, A.A. Chávez-Durán, J.L. Zavala-Aguirre, J. Cerano-Paredes, and A.R. Martínez-Sifuentes. 2018. Respuesta climática de Pinus oocarpa Schiede ex Schetol en el Bosque La Primavera, Jalisco. Madera y Bosques 24 (1): e2411464. [In Spanish.] https://doi.org/10.21829/ myb.2018.2411464

Yocom, L., P. Fulé, P. Brown, J. Cerano-Paredes, J. Villanueva-Díaz, D. Falk, and E. Cornejo-Oviedo. 2010. El Niño-Southern Oscillation effect on a fire regime in northeastern Mexico has changed over time. Ecology 91 (6): 1660-1671. https://doi.org/10.1890/09-0845.1.

Yocom, L., and P.Z. Fulé. 2012. Human and climate influences on frequent fire in a high-elevation tropical forest. Journal of Applied Ecology 4: 1356-1364. https://doi.org/10.1002/ecs2.1932.

Yocom, L., P.Z. Fulé, P.M. Brown, J. Cerano-Paredes, E. Cornejo-Oviedo, C. CortésMontaño, S.A. Drury, D.A. Falk, J. Meunier, H.M. Poulos, C.N. Skinner, S.L. Skinner, S.L. Stephens, and J. Villanueva-Díaz. 2017. Climate drives fire synchrony but local factors control fire regime change in northern Mexico. Ecosphere 8 (3): 1-13. https://doi.org/10.1002/ecs2.1709.

\section{Submit your manuscript to a SpringerOpen ${ }^{\circ}$ journal and benefit from:}

- Convenient online submission

- Rigorous peer review

- Open access: articles freely available online

- High visibility within the field

- Retaining the copyright to your article

Submit your next manuscript at $\boldsymbol{\sim}$ springeropen.com 